\title{
Roles of Glyceraldehyde-3-Phosphate Dehydrogenase in Edwardsiella tarda Pathogenesis
}

\author{
Jong Earn Yu, Young Eun Oh, Tae Ho Lee and Ho Young Kang* \\ Department of Microbiology, Pusan National University, Busan 609-735, Korea
}

Received June 3, 2010 / Accepted December 23, 2010

\begin{abstract}
A research group demonstrated that the $37 \mathrm{kDA}$ protein of Edwardsiella tarda, a causing causative agent of edwardsiellosis in fish, exhibited high antigenicity in Japanese flounder. The research group also showed that the N-terminus amino acid sequences of the $37 \mathrm{kDa}$ protein were mapped to the $\mathrm{N}$-terminus of GAPDH (glyceraldehyde-3-phosphate dehydrogenase). Using degenerated primer sets based on the known N-terminus sequence, the corresponding E. tarda DNA was amplified and cloned. The nucleotide sequences of the cloned gene revealed high homology with a bacterial gene for GAPDH, as we was expected. The amino acid sequence of $E$. tarda GAPDH (etGAPDH) revealed a $<70 \%$ similarity with GAPDH proteins in other Enterobacteriaceae. With the application of artificial protein overexpression system in Escherichia coli, the recombinant etGAPDH (rGAPDH) was produced and purified. In this study, Using the purified rGAPDH, the etGAPDH specific polyclonal antibody has been was generated using the purified rGAPDHin this study. The immunoblotting analyses demonstrated that the location of the GAPDH protein is located with the association of is associated with the envelops of $E$. tarda. The rGAPDH was administrated into Japanese flounder via IP route for evaluation of the protective ability. Although the specific antibody titer against etGAPDH was increased about 3-fold after 4 weeks post-vaccination, the survival rates of vaccinated Japanese flounder and the control group with wild type E. tarda was were $12.5 \%$ and $0 \%$, respectively. Our results indicated that rGAPDH is immunoreactive antigen but that it will not generate protective immunity in Japanese flounder.
\end{abstract}

Key words : Edwardsiella tarda, vaccine, pathogenesis

\section{Introduction}

Edwardsiella tarda is the causative agent of the systemic disease, edwardsiellosis, in many freshwater and marine fish in both farmed and wild populations around the world [16]. Edwardsiellosis causes high mortalities and severe economic losses in farmed fish, such as flounders [17], eels [27], tilapia [11], carp [19], channel catfish [14], and others. Several potential virulence factors of $E$. tarda have been reported. The abilities to invade epithelial cells [9,12], serum resistance [25], phagocyte-mediated killings [23], a type III secretion system (TTSS) [13], and production of toxin and enzymes, such as hemolysins [7], and catalyses [24] have been found to play important roles in E. tarda pathogenesis.

The outer membrane of pathogenic bacteria has an important role in the induction of immune response including humoral and cell-mediated immunity [10]. The outer membrane interacts with hosts in the bacterial pathogenesis during adherence, uptake of nutrients from the host, and elimi-

\footnotetext{
*Corresponding author

Tel : +82-51-510-2266, Fax : +82-51-513-4532

E-mail : hoykang@pusan.ac.kr
}

nating host defense mechanisms, because the components of the outer membrane are easily recognized as foreign substances by the host immune defense system [21]. Up to date little is known about immune responses by induced $E$. tarda surface protein antigen. Recent studies emphasized the role of the outer membrane protein of pathogenic bacteria in protective immunity $[2,14,19]$, which is often related to inducing neutralization of antibodies [2], inhibiting bacterial colonization in hosts [27], and inducing cell-mediated immunity [1].

In a recent study, the $37 \mathrm{kDa}$ protein of $E$. tarda exhibited strong immune responses in fish [6]. The protein was existed in all of the $E$. tarda isolates, and highly conserved regardless of the serotype. The N-terminal amino acid sequence of this protein showed high homology to GAPDH (glyceraldehyde-3-phosphate dehydrogenase) [6]. GAPDH is one of a major enzyme, which is involved in energy production [28]. Some reports indicated that GAPDH binds to a cell membrane $[1,15,26]$ and exists on the cell surface $[8,18]$. In this study, we were interested in the antigenic role of the GAPDH, which is conserved in different serotypes of E. tarda. We hypothesized that GAPDH is a surface protein as antigen to induce immune responses, and we wonder 
whether it can stimulate protective immunity. The aim of this report is identifying the role of GAPDH in E. tarda pathogenesis.

\section{Materials and Methods}

\section{Bacterial strains and growth conditions}

The bacterial strains and plasmids used in this study are listed in Table 1. E. coli used as hosts for cloning and protein expression were grown at $37^{\circ} \mathrm{C}$ in Luria-Bertani (LB) broth or LB agar [3]. E. tarda, was isolated from flounder and provided by the National Fisheries Research and Development Institute (NFRDI) in the Republic of Korea, were grown at $27^{\circ} \mathrm{C}$ in tryptic soy broth (TSB) or on tryptic soy agar (TSA) (Difco) containing $1 \% \mathrm{NaCl}$ [22]. Antibiotics, when required, were added in the culture medium with the following concentrations; ampicillin, $100 \mu \mathrm{g} / \mathrm{ml}$; tetracycline, $15 \mu \mathrm{g} / \mathrm{ml}$; chloramphenicol, $30 \mu \mathrm{g} / \mathrm{ml}$; and streptomycin, $50 \mu \mathrm{g} / \mathrm{ml}$.

\section{General DNA manipulations}

DNA manipulations, including DNA preparation, ligation, restriction analysis, transformation and electrophoresis were carried out as described by Sambrook et al [20]. Genomic DNA of E. tarda was extracted by using the AccuPrep Genomic DNA Extraction Kit (Bioneer). PCR amplification was employed to obtain DNA fragments for cloning. The PCR conditions were as follows: denaturation at $95^{\circ} \mathrm{C}$ for $30 \mathrm{sec}$, primer annealing at $50^{\circ} \mathrm{C}$ for $30 \mathrm{sec}$, polymerization at $72^{\circ} \mathrm{C}$ for $1 \mathrm{~min}$, and a final extension at $72^{\circ} \mathrm{C}$ for $10 \mathrm{~min}$. Transformation of E. coli were done by either rubidium chloride-heat shock or electroporation (BioRad).

\section{Primer design for amplifying of $E$. tarda GAPDH}

The nucleotide sequences of the GAPDH gene of four
Gram-negative bacteria, Salmonella typhimurium, Yersinia pestis, Erwinia carotovora, E. coli, were obtained by NCBI database, and the homologies of their GADPH nucleotide sequence were compared by using the NCBI homology alignment system. Both primers for the amplification of forward and reverse were designed from the conserved GAPDH nucleotide sequences at the $5^{\prime}$ and $3^{\prime}$ ends.

\section{Heterologous overexpression of GAPDH}

A DNA fragment encoding E. tarda GAPDH was amplified from chromosomal DNA using a pair of primers HY205F (GC GGATCC GCA TAC ATG CTG AAG) and HY206R (GC AAGCTT CAG TTT CAC GAA GTT), which were synthesized based on the gapA sequence of $E$. tarda. Italicized residues in the primer sequence show the cutting site of BanHI and HindIII, respectively. The BamHI-HindIII DNA fragment was cloned into pProEx ${ }^{\mathrm{TM}} \mathrm{HTb}$ vector (Invitrogen), resulting in the pBP356. E. coli BL21 (DE3) cells harboring pBP356 were grown in LB broth, and the recombinant protein was induced by the addition of $1 \mathrm{mM}$ IPTG. Purification of the recombinant protein was performed by the instructions of the manufacturer (GE Healthcare). Most of the expressed recombinant protein existed in $E$. coli as an insoluble form. The proteins were solubilized using $8 \mathrm{M}$ urea and purified by affinity chromatography with $\mathrm{Ni}^{2+}$-sepharose (GE Healthcare).

\section{SDS-PAGE and immunoblot analysis}

Protein samples were solubilized in $2 \times$ digestion buffer [20\% (v/v) glycerol, $4 \%$ (w/v) SDS, $0.2 \%$ (w/v) bromophenol blue, $200 \mathrm{mM} \beta$-mercaptoethanol, $100 \mathrm{mM}$ Tris- $\mathrm{HCl} \mathrm{pH}$ 6.8] by boiling for $5 \mathrm{~min}$, and separated by discontinuous sodium dodecyl sulfate-polyacrylamide gel electrophoresis (SDS-PAGE). Proteins were visualized by Coomassie brilliant blue G-250 (Sigma) staining.

Table 1. Bacterial strains and plasmids used in this study

\begin{tabular}{|c|c|c|}
\hline Strains and plasmids & Characteristics & Reference \\
\hline \multicolumn{3}{|l|}{ Strains } \\
\hline E. tarda CK108 & Wild type, isolate from flounder developed edwardsiellosis & NFRDI \\
\hline E. coli $\mathrm{DH} 5 \mathrm{a}$ & Transformation host for cloning vector & Promega \\
\hline E. coli BL21 (DE3) & Host for overexpression, $\mathrm{F}^{-}$ompT $h s d S_{B}\left(r_{B}^{-} r n_{B}^{-}\right)$gal dcm $\lambda$ (DE3) & Promega \\
\hline \multicolumn{3}{|c|}{ 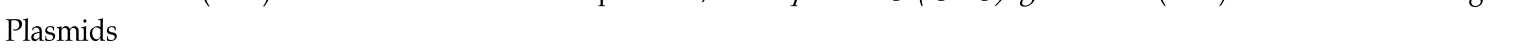 } \\
\hline pProEx ${ }^{\mathrm{TM}} \mathrm{THb}$ & Overexpression vector, $\mathrm{Lacl}^{\mathrm{q}}$ ColE1 $\mathrm{Ap}^{\mathrm{R}}$ & Invitrogen \\
\hline pGEM-T & Cloning vector for PCR product, ColE1 $\mathrm{Ap}^{\mathrm{R}}$ & Promega \\
\hline pBP237 & $1.0 \mathrm{~kb}$ DNA containing gap $A$ in $\mathrm{pGEX}-\mathrm{T}$ vector, $\mathrm{Ap}^{\mathrm{R}}$ & This study \\
\hline pBP356 & $1.0 \mathrm{~kb}$ gapA BanHI-HindIII product from $\mathrm{pBP} 237$ in $\mathrm{pProEX}^{\mathrm{TM}} \mathrm{THb}$ & This study \\
\hline
\end{tabular}


For immunoblotting, proteins separated by SDS-PAGE were transferred to nitrocellulose membrane in Towbin's buffer. The membrane was blocked with a blocking solution (5\% skim milk in Towin's saline buffer) for $3 \mathrm{hr}$ as described by Towbin et al [5]. The membrane was incubated with a suitable diluted rabbit or mouse antisera in the blocking solution for $2 \mathrm{hr}$ and followed by 1:2,000 dilution of a horseradish peroxidase conjugated goat anti-rabbit IgG (Pierce) or anti-mouse IgG (Sigma) in the blocking solution. Immunoreactive bands were detected by the addition of 4-chloro-1-naphthol (Sigma) in the presence of $\mathrm{H}_{2} \mathrm{O}_{2}$ (Sigma). The reaction was stopped after $5 \mathrm{~min}$ by washing with several changes with a large volume of deionized water.

\section{Preparation of the outer membrane protein fraction}

E. tarda cells were collected by centrifugation at $8,000 \times$ $g$ for $5 \mathrm{~min}$, and suspended in $20 \mathrm{mM}$ Tris- $\mathrm{HCl}$ (pH 8.0) and disrupted by French press (Thermo Electron Cooperation) at 18,000 psi. The lysate was centrifuged at $4,500 \times g$ for $5 \mathrm{~min}$ to remove unbroken cells. The total membrane pellet was obtained by centrifugation at $27,000 \times \mathrm{g}$ at $4^{\circ} \mathrm{C}$ for $1 \mathrm{hr}$, and treated with $1 \%$ lauryl sarcosine (Sigma). Then, the outer membrane protein was obtained as a pellet after centrifugation at $27,000 \times g$ at $4^{\circ} \mathrm{C}$ for $1 \mathrm{hr}$. The pellet was resuspended in $10 \mathrm{mM}$ Tris- $\mathrm{HCl}(\mathrm{pH} \mathrm{8.0)}$.

\section{ELISA (Enzyme-linked immunosorbent assay)}

ELISA 96-well plates (Corning) were coated with $1 \mathrm{ng} / \mu \mathrm{l}$ of GAPDH in $50 \mathrm{mM}$ sodium carbonate ( $\mathrm{pH}$ 9.6). The plates were blocked with $200 \mu \mathrm{l}$ of blocking buffer (1\% BSA in PBS, $\mathrm{pH}$ 7.4) per each well to avoid non-specific binding. After remove blocking buffer, $100 \mu \mathrm{l}$ of serially diluted samples were added into each well, and washed 5 times with 250 $\mu l$ of PBS. Then, the plates were incubated with biotin conjugated goat anti-rabbit IgG or anti-mouse IgG (Southern Biotech) $(1: 10,000$ in $0.1 \%$ BSA in PBS), and washed with PBS. Finally, the plates were incubated with alkaline phosphatase labeled streptavidin (Southern Biotech) $(1: 3,000$ in $0.1 \%$ BSA in PBS). The $\rho$-nitrophenylphosphate $(1 \mathrm{mg} / \mathrm{ml})$ (Sigma) in 0.1 M diethanolamine buffer ( $\mathrm{pH} 9.8$ ) was used as the substrate. The optical density of the color reaction was read at $405 \mathrm{~nm}$ with an automated ELISA reader (GE Healthcare).

\section{Results and Discussion}

\section{Determination of nucleotide sequence of $E$. tarda gapA}

To identify nucleotide sequence of $E$. tarda GAPDH gene, the DNA fragment encoding the gapA was amplified by PCR. An approximately $1.0 \mathrm{~kb}$ length of amplified DNA fragment was cloned into pGEM-T vector (Promega), resulting in pBP237, and its nucleotide sequence was analyzed

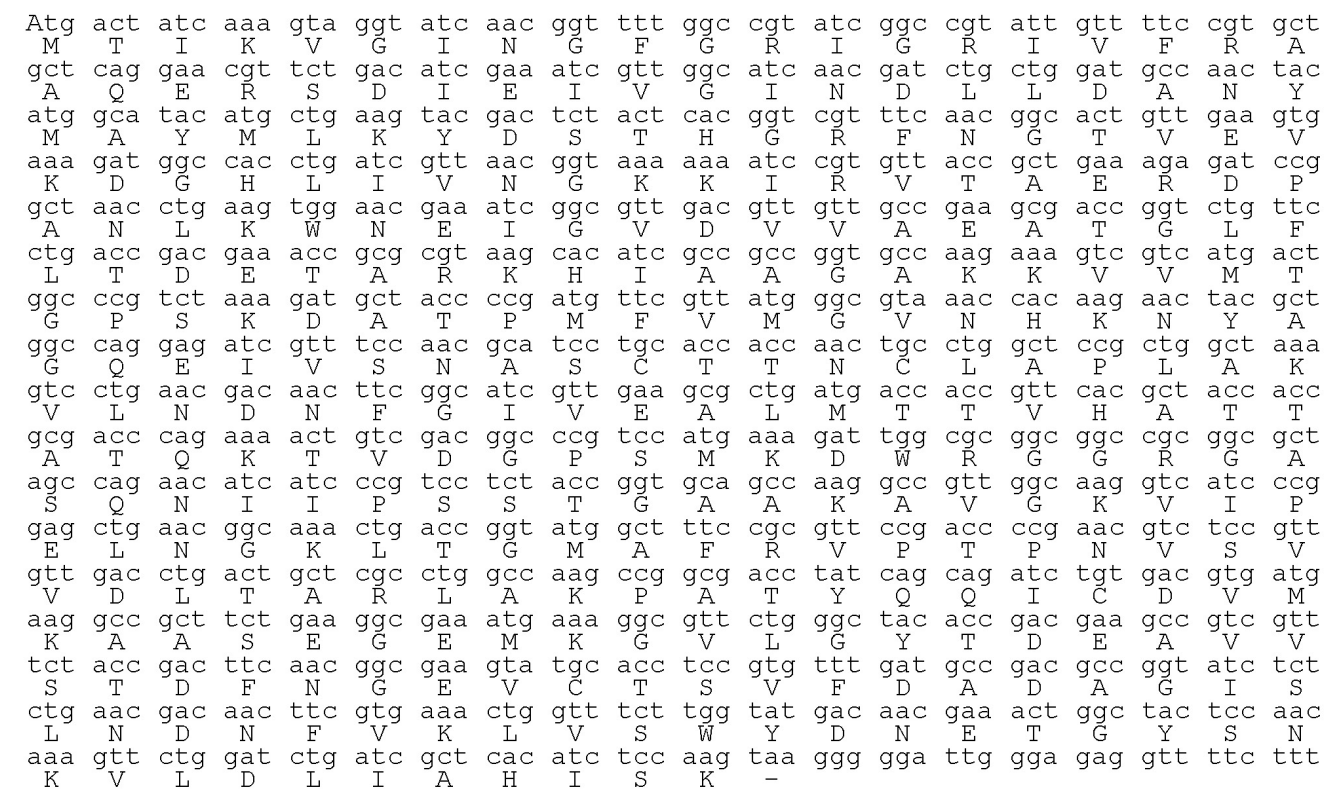

Fig. 1. Full length nucleotide sequence of the $E$. $\operatorname{tarda}$ gap $A$ and its deduced amino acid sequence. The 990 bp of nucleotide and encoded amino acid sequence are shown. 
by DNA auto sequencer (ABI PRISM 377, Perkin Elmer) (Fig. 1). The DNA fragment contained the full sequence of the gapA, and the GAPDH was composed of 331 amino acid residues. The homologies of the GAPDH amino acid sequence between $E$. tarda and the other Enterobacteriaceae family were compared by using the BLAST search engine. The GAPDH of $E$. tarda showed $<70 \%$ similarity with other Enterobacteriaceae GAPDH proteins (Table 2).

\section{Subcellular location of GAPDH protein in E. tarda}

To verify the location of the GAPDH in the outer membrane, we generated an antiserum against the $E$. tarda outer membrane proteins (OMPs). The OMPs of $E$. tarda were prepared as described above and $20 \mu \mathrm{g}$ of $E$. tarda OMPs were administrated to $B A L B / c$ by the intraperitoneal route. After 4 weeks of post administration, BALB/c mice were boosted with the same amount of $E$. tarda OMPs. After 2 weeks of post boosting, the blood of BALB/c was collected from the vein on the marginal part of the eyes. The recombinant GAPDH, prepared as described in Materials and Methods (Fig. 3A), was detected by immunoblot analysis using E. tarda OMPs specific polyclonal antibodies, and the same position of reactive band was also detected in E. tarda total lysate (Fig. 2). These results suggest that the GAPDH exists in the outer membrane as well as cytosol.

\section{Preparation of GAPDH specific polyclonal antibodies}

To generate GAPDH specific antibodies, $120 \mathrm{\mu g}$ of the recombinant GAPDH emulsified with the same volume of Freund's complete adjuvant (Sigma) as antigen. The antigen was administrated to the New Zealand White rabbit by intramusclar, after 3 weeks post administration, the rabbit was boosted with the same amount of antigen used in the primary administration mixed with incomplete Freund's adjuvant (Sigma). The bloods were collected from the vein on

Table 2. Amino acid similarity of E. tarda GAPDH compared with other bacteria

\begin{tabular}{ll}
\hline Bacteria & Identities (\%) \\
\hline Yersinia pestis biovar Medievalis str. 91001 & $839 / 994(84 \%)$ \\
Shigella flexneri 2a str. 301 & $632 / 731(86 \%)$ \\
Escherichia coli O157:H7 & $632 / 731(86 \%)$ \\
Escherichia coli K-12 & $631 / 731(86 \%)$ \\
Erwinia carotovora subsp. atroseptica & $637 / 742(85 \%)$ \\
Salmonella typhimurium LT2 & $620 / 725(85 \%)$ \\
Serratia sp. & $590 / 689(85 \%)$ \\
\hline
\end{tabular}

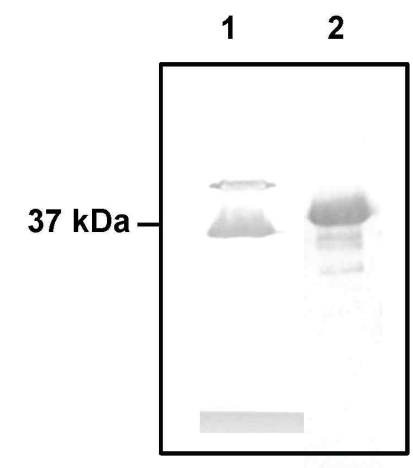

Fig. 2. Confirmation of the GAPDH protein in E. tarda. Protein samples were subjected to immunoblot analysis. The interested proteins were visualized by reactivity with mouse anti-E. tarda outer membrane proteins (OMPs) antibodies. Lane 1, E. tarda total lysate; 2, recombinant GAPDH.
A.

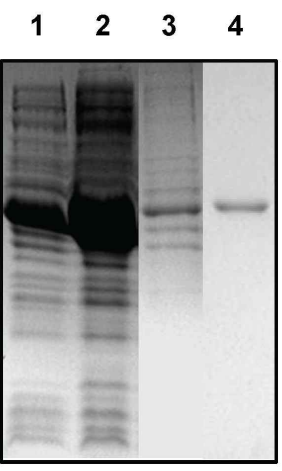

B.

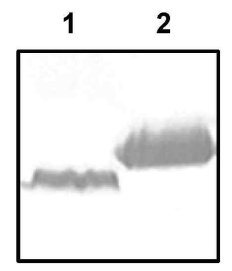

Fig. 3. Overexpression and immunoblot analysis of the GAPDH. (A) SDS-PAGE analysis of overexpressed GAPDH. The (His) ${ }_{6}$-tagged GAPDH expression in E. coli BL21 (DE3) harboring pBP356 was induced by addition of $1 \mathrm{mM}$ IPTG into LB broth. Lane 1, cell lysates; 2, soluble fraction; 3, insoluble fraction. of $E$. coli BL21 (DE3) harboring pBP356 (B) Immunoblot analysis for confirmation of generated antibodies against GAPDH. Lane 1, E. tarda outer membrane protein (OMPs); 2, the recombinant GAPDH.

the marginal part of the ears at every step. Two weeks after boosting, the rabbit sacrificed to collect sera. The production of anti-GAPDH polyclonal antibodies was evaluated by immunoblot assay and ELISA. The recombinant GAPDH showed a strong reaction (Fig. 3B) and specific antibodies titer measured $\log _{2} 9$ to $\log _{2} 13$, which were sera after the first administration and boosted, respectively (Fig. 4). These results indicated that anti-GAPDH antibodies were successfully produced. 


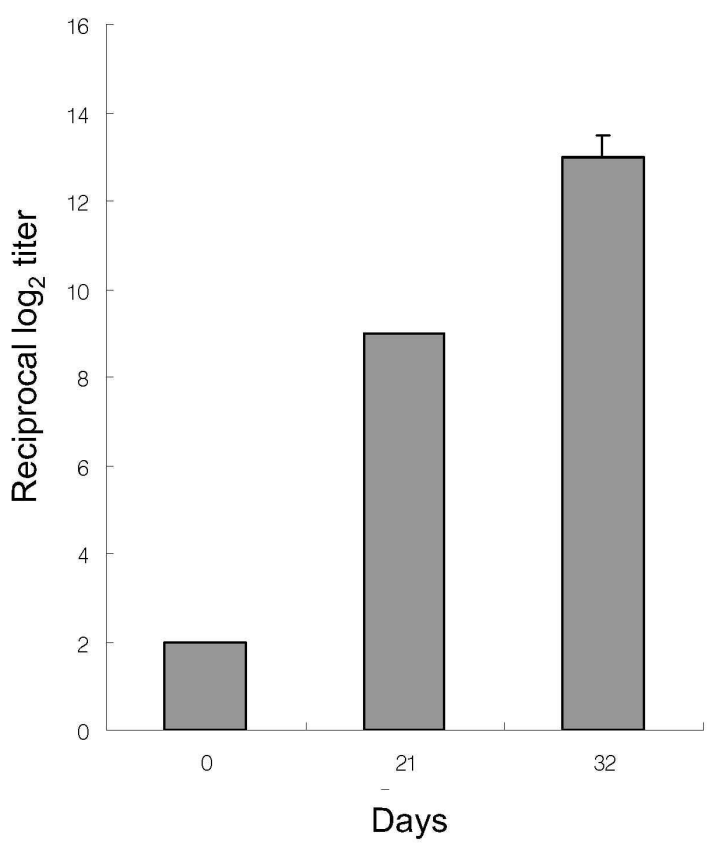

Fig. 4. Titration of the anti-GAPDH IgG from rabbit. Specific antibody titer by ELISA in the sera of rabbit after immunization of GAPDH. The sera were diluted in a series of two-fold.

Evaluation of the protection ability of GAPDH challenged with E. tarda in flounder

The Japanese flounder (body weight 50 to $100 \mathrm{~g}$ ) was maintained in the National Fisheries Research and Development Institute under laboratory conditions. The Japanese flounders were vaccinated with $10 \mu \mathrm{g}$ and $100 \mu \mathrm{g}$ of the recombinant GAPDH by intraperitoneal route. After 4 weeks of post-vaccination, the fish were challenged with $5.0 \times 10^{8} \mathrm{CFU}$ of E. tarda. At 4-7 days after challenge, all the fish in the unvaccinated group had died and most of the fish in the vaccinated group with GAPDH had also died. Survival rate of the vaccinated groups was $12.5 \%$ (Fig. 5). A specific antibody titer against GAPDH was detected in the vaccinated flounder sera by using ELISA. The antibody titer was increased three-fold after 4 weeks (data not shown).

$E$. tarda is causes a systemic fish disease called edwardsiellosis [4]. In a recent study, the $37 \mathrm{kDa}$ protein of E. tarda was suggested to have and antigenicity [13]. The $37 \mathrm{kDa}$ protein was identified as a GAPDH, which is involved in energy production [28]. We focused on the roles of GAPDH in $E$. tarda pathogenesis, To investigate the roles of GAPDH, the E. tarca gap $A$ gene was amplified and its nucleotide sequence was analyzed. The nucleotide and amino acid sequence of GAPDH revealed a strong similarity with other

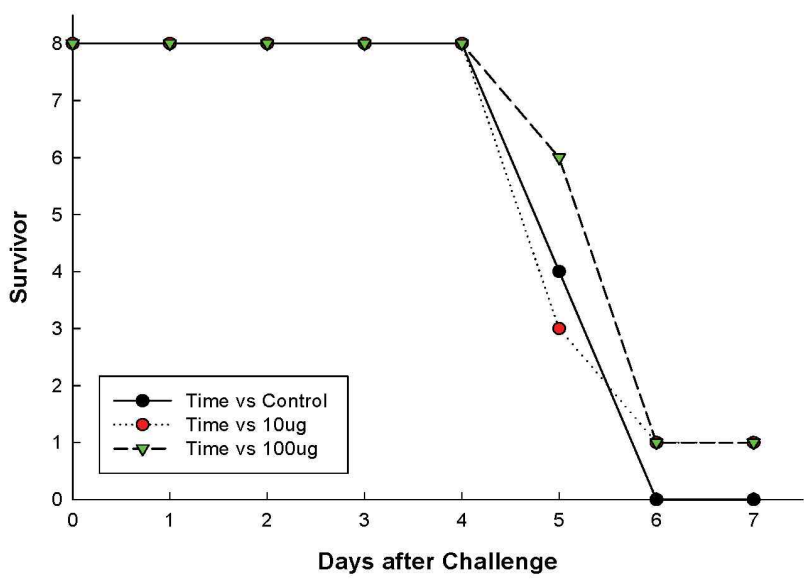

Fig. 5. Protection ability of GAPDH challenged with E. tarda in Japanese flounder. The recombinant GAPDH and PBS was immunized as a vaccinated and control, respectively. The Japanese flounders were vaccinated with 10 and 100 $\mu \mathrm{g}$ of GAPDH. After 4 weeks of post vaccination, the fish were injected with $5.0 \times 10^{8} \mathrm{CFU}$ of $E$. tarda, and mortality observation were recorded for 8 days.

Enterobacteriaceae GAPDH proteins. Its high homologue indicates that the gap $A$ gene is well conserved in the evolution process. To confirm the location of GAPDH, we generated anti-E. tarda OMPs antibodies, and detected the recombinant GAPDH by immunoblot analysis using specific antibodies. To examine the role of GAPDH as a protective antigen, the protective ability of GAPDH against $E$. tarda infection in the Japanese flounders was performed. Fish were intraperitoneally immunized with the recombinant GAPDH, and the fish were challenged with $E$. tarda. No significant difference between the vaccinated and the unvaccinated groups was observed. The reason for this result could be explained that challenge dose of $E$. tarda was excessed. Indeed, the $\mathrm{LD}_{50}$ of E. tarda was measured to be $3.0 \times 10^{6} \mathrm{CFU}$, but the challenge dose of $E$. tarda used for this study was $5.0 \times 10^{8} \mathrm{CFU}$, almost an 200-fold higher dose. This report is study to identify antigen and examine whether it is functioning as a vaccine candidate. The results of this study will be used as a basis to develop an effective vaccine.

\section{Acknowledgment}

This work was supported for two years by Pusan National University Research Grant.

\section{References}

1. Allen, R. and K. Trach. 1987. Identification of the $37-\mathrm{kDa}$ 
protein displaying a variable interaction with the erythroid cell membrane as glyceraldehyde-3-phosphate dehydrogenase. J. Biological Chemistry 262, 649-653.

2. Amandi, A., S. F. Hiu, J. S. Rohovec, and J. L. Fryer. 1982. Isolation and characterization of Edwardsiella tarda from fall chinook salmon (Oncorhynchus tshawytscha). Appl. Environ. Microbiol. 43, 1380-1384.

3. Bertani, G. 1951. Studies on lysogenesis I.: The mode of phage liberation by lysogenic Escherichia coli. J. Bacteriol. 62, 293-300.

4. Durrieu, C. and F. Bernier-Valentin. 1987. Microtubules bind glyceraldehyde 3-phosphate dehydrogenase and modulate its enzyme activity and quaternary structure. Arch Biochem Biophys. 252, 32-40.

5. Edwards, R. and L. Keller. 1998. Improved allelic exchange vectors and their use to analyze 987P fimbria gene expression. Gene 207, 149-157.

6. Erttmann, K., A. Kleensang, E. Schneider, S. Hammerschmidt, D. W. Büttner, and M. Gallin. 2005. Cloning, characterization and DNA immunization of an Onchocerca volvulus glyceraldehyde-3-phosphate dehydrogenase (OV-GAPDH). Biochim Biophys. Acta. 1741, 85-94.

7. Hirono, I., N. Tange, and T. Aoki. 1997. Iron-regulated haemolysin gene from Edwardsiella tarda. Mol. Microbiol. 24, 851-856.

8. Hughes, M. J., J. C. Moore, J. D. Lane, R. Wilson, P. K. Pribul, Z. N. Younes, R. J. Dobson, P. Everest, A. J. Reason, J. M. Redfern, F. M. Greer, T. Paxton, M. Panico, H. R. Morris, R. G. Feldman, and J. D. Santangelo . 2002. Identification of major outer surface proteins of Streptococcus agalactiae. Infect. Immun. 70, 1254-1259.

9. Janda, J. M., S. L. Abbott, S. Kroske-Bystrom, W. K. Cheung, C. Powers, R. P. Kokka, and K. Tamura. 1991. Pathogenic properties of Edwardsiella species. J. Clin. Microbiol. 29, 1997-2001

10. Kawai, K., Y. Liu, K. Ohnishi, and S. Oshima. 2004. A conserved $37 \mathrm{kDa}$ outer membrane protein of Edwardsiella tarda is an effective vaccine candidate. Vaccine 22, 3411-3418.

11. Kubota, S., T. Miyazaki, and T. Miyashita. 1982. Histopathological studies on edwardsiellosis of tilapia, 1: Natural infection. Bull. Faculty Fish 9, 155-165.

12. Ling, S. H., X. H. Wang, L. Xie, T. M. Lim, and K. Y. Leung. 2000. Use of green fluorescent protein (GFP) to study the invasion pathways of Edwardsiella tarda in in vivo and in vitro fish models. Microbiology 146 (Pt 1), 7-19.

13. Liu, Y., S. Oshima , K. Kurohara, K. Ohnishi, and K. Kawai. 2005. Vaccine efficacy of recombinant GAPDH of Edwardsiella tarda against Edwardsiellosis. Microbiol. Immunol. 49, 605-612.

14. Meyer, F. P. and G. L. Bullock. 1973. Edwardsiella tarda, a new pathogen of channel catfish (Ictalurus punctatus). Appl. Microbiol. 25, 155-156.

15. Modun, B. and P. Williams. 1999. The staphylococcal transferrin-binding protein is a cell wall glyceraldehyde-3-phosphate dehydrogenase. Infect Immun. 67, 1086-1092.

16. Mohanty, B. R. and P. K. Sahoo. 2007. Edwardsiellosis in fish: a brief review. J. Biosci. 32, 1331-1344.

17. Nakatsugawa, T. 1983. Edwardsiella tarda isolated from cultured young flounder [Paralichthys olivaceus, in Japan]. Fish Pathology 18, 99-101.

18. Pancholi, V. and V. A. Fischetti. 1992. A major surface protein on group A streptococci is a glyceraldehyde-3-phosphate-dehydrogenase with multiple binding activity. J. Exp. Med. 176, 415-426.

19. Sae-Oui, D. and K. Muroga. 1984. A case of Edwardsiella tarda infection in cultured colored carp Cyprinus carpio. Fish Pathology (Japan) 19, 197-199.

20. Sambrook, J. and D. W. Russell. 2001. Molecular Cloning a laboratory manual, 3rd eds. Cold spring Harbor Laboratory Press, Cold Spring Harbor, New York.

21. Seltmann, G. and O. Holst. 2002. The bacterial cell wall , Springer-Verlag, Heidelberg, New York.

22. Shotts, E. B. and W. D. Waltman. 1990. A medium for the selective isolation of Edwardsiella ictaluri. J. Wildl. Dis. 26, 214-218.

23. Srinivasa Rao, P. S., T. M. Lim, and K. Y. Leung. 2001. Opsonized virulent Edwardsiella tarda strains are able to adhere to and survive and replicate within fish phagocytes but fail to stimulate reactive oxygen intermediates. Infect Immun. 69, 5689-5697.

24. Srinivasa Rao, P. S., Y. Yamada, and K. Y. Leung. 2003. A major catalase (KatB) that is required for resistance to $\mathrm{H} 2 \mathrm{O} 2$ and phagocyte-mediated killing in Edwardsiella tarda. Microbiology (Reading, Engl). 149, 2635-2644.

25. Thune, R., L. Stanley, and R. Cooper. 1993. Pathogenesis of gram-negative bacterial infections in warmwater fish. Ann. Review Fish Dis. 3, 37-68.

26. Tsai, I. H. and S. N. Murthy, and T. L. Steck. 1982. Effect of red cell membrane binding on the catalytic activity of glyceraldehyde-3-phosphate dehydrogenase. J. Biol. Chem 257, 1438-1442.

27. Wakabayashi, H. and S. Egusa. 1973. Edwardsiella tarda (Paracolobactrum anguillimortiferum) associated with pond-cultured eel disease. Bull. Jpn. Soc. Sci. Fish 39, 931-936.

28. Yamaji, R., E. Chatani, N. Harada, K. Sugimoto, H. Inui, and Y. Nakano. 2005. Glyceraldehyde-3-phosphate dehydrogenase in the extracellular space inhibits cell spreading. Biochim Biophys. Acta. 1726, 261-271. 
초록 : Edwardsiella tarda의 glyceraldehyde-3-phosphate dehydrogenase가 병원성에 미치는 영향

유종언 · 오영은 · 이태호 · 강호영*

(부산대학교 미생물학과)

Edwardsiella tarda는 그람 음성의 장내세균과의 주요 어병세균으로 어류에 edwardsiellosis를 유발하는 전신감 염성 병원체이다. 최근 병원성 세균의 외막 단백질들은 세균성 감염에 있어서 숙주와 반응하여 면역반응을 유도 하는 것으로 여겨져 연구가 되고 있다. 일본의 연구팀은 어류에서 에드워드병의 원인체인 $E . \operatorname{tarda}$ 의 $37 \mathrm{kDa}$ 단백 질이 넙치에서 높은 항원성을 제시하는 것을 보고하였다. 또한 그 연구자들은 $37 \mathrm{kDa}$ 단백질의 $\mathrm{N}$-말단 아미노산 서열이 GAPDH와 대응하는 것을 밝혔다. 본 연구에서는 다른 세균에서 알려진 $\mathrm{N}$-말단 서열을 기반으로 primer 를 제작하여 이에 상응하는 $E$. $\operatorname{tarda} \mathrm{DNA}$ 를 증폭하고 클로닝하였다. 이 DNA단편의 염기서열은 예상한 바와 같 이 세균의 GAPDH유전자인 gapA와 높은 상동성이 있고, E. $\operatorname{tarda} \mathrm{GAPDH}$ (etGAPDH)의 아미노산 서열은 다른 장내세균의 $\mathrm{GAPDH}$ 와 $70 \%$ 이상의 상동성을 보이는 것을 확인하였다. E. tarda의 외막단백 질에 특이적으로 반응 하는 항체를 이용하여 $E$. $\operatorname{tard} d$ 의 GAPDH가 외막에 존재한다는 것을 증명하였고, gapA의 염기서열을 바탕으로하 여 재조합 GAPDH를 과발현 시켰다. 과발현된 재조합단백질 GAPDH는 GAPDH 특이적인 항체를 제조하는데 사용되었고, 또한 넙치에 면역시켜 단일 단백질 백신으로서의 활용도를 모색하였다. 비록 재조합 GAPDH가 면역 된 넙치에서 GAPDH에 특이적인 항체가 증가하였음에도 불구하고, E. tarda로 공격실험을 하였을 때 면역된 넙 치의 생존율이 $12.5 \%$ 로 측정되어 면역된 그룹과 면역되지 않은 그룹간에 큰 차이가 없는 것이 확인되었다. 